\title{
The Investigation of the Effect of Montessori Approach-based STEM Activities on the Problem-solving Skills of Pre-service Preschool Teachers*
}

\section{Montessori Yaklaşım Temelli STEM Etkinliklerinin Okul Öncesi Öğretmen Adaylarının Problem Çözme Becerilerine Etkisi}

\author{
Zehra ÇAKIR $^{* *}$ iD
}

\author{
Sema ALTUN-YALÇIN ${ }^{* * *}$ (D)
}

Received: 11 November 2020

Research Article

Accepted: 13 February 2021

ABSTRACT: This research was conducted to determine whether there is any effect of the Montessori approachbased STEM activities on the development of the problem-solving skills of pre-service preschool teachers or not. The mixed-method was employed in the research. The sample of the research consisted of 50 teacher candidates studying at the Faculty of Education Preschool Teaching Department in the 2017-2018 academic year. A single grouped pretest-posttest pattern was created to determine the difference in the problem-solving skills of the pre-service teachers in the research. The quantitative data gathered during the process of the research were analysed with the statistical methods; the qualitative data were analysed with the content analysis. In the study, quantitative data were collected using the "Problem Solving Scale", and qualitative data were collected using the "Semi-Structured Interview Form". The interview form is quantitative and consists of 10 open-ended questions in total. This form was applied only to 15 volunteers at the end of the study. For 14 weeks, candidates were given Montessori approachbased STEM training. In the findings obtained as a result of the research; it was observed that there was a significant difference between the pre-test and post-test scores of problem-solving skills and the qualitative analysis results also supported the quantitative results. With these findings, it was concluded that the activities developed the problemsolving skills of individuals and produced solutions to the problem from different perspectives.

Keywords: Montessori approach, problem-solving, STEM.

ÖZ: $\mathrm{Bu}$ araştırma, Montessori yaklaşım temelli STEM etkinliklerinin okul öncesi öğretmen adaylarının; problem çözme becerilerinin gelişimi üzerine etkisinin olup olmadığını tespit etmek amacıyla yapılmıştır. Araştırmada karma yöntem kullanılmıştır. Araştırma örneklemini 2017-2018 eğitim öğretim yılında Eğitim Fakültesi Okul Öncesi Öğretmenliği Bölümünde öğrenim gören 50 öğretmen adayı oluşturmuştur. Araştırmada öğretmen adaylarının problem çözme becerilerindeki değişimi belirlemek amacıyla tek gruplu öntest sontest deseni oluşturulmuştur. Araştırma süresince elde edilen nicel verilerin analizi istatistiksel yöntemler ile nitel verilerin analizi ise içerik analizi ile yapılmıştır. Çalışmada nicel veriler "Problem Çözme Ölçeği” ile nitel veriler ise "Yarı-Yapılandırılmış Görüşme Formu" kullanılarak toplanmıştır. Görüşme formu niceli destekleyici nitelikte ve toplamda 10 açık uçlu sorudan oluşmaktadır. Bu form çalışma sonunda sadece gönüllü 15 katılımcıya uygulanmıştır. 14 hafta boyunca adaylara Montessori yaklaşım temelli STEM eğitimleri verilmiştir. Araştırma sonucunda elde edilen bulgularda; problem çözme becerilerinin öntest ve sontest puanları arasında, anlamlı bir farklılık olduğu ve yapılan nitel analiz sonuçlarının da nicel sonuçları desteklediği gözlenmiştir. Bu bulgular ile etkinliklerin bireylerin problem çözme becerilerini geliştirdiği ve soruna farklı bakış açıları ile çözümler ürettikleri sonucuna ulaşılmıştır.

Anahtar kelimeler: Montessori yaklaşımı, problem çözme, STEM.

\footnotetext{
* This study was produced from the master's thesis of the first author under the supervision of the second author at Erzincan Binali University.

** Corresponding Author: MA student, Erzincan Binali Y1ldırım University, Erzincan, Turkey, zehracakir.29@hotmail.com, https://orcid.org/0000-0003-4585-8214

*** Prof. Dr., Erzincan Binali Yıldırım University, Erzincan, Turkey, saltun_11@hotmail.com, https://orcid.org/0000-0001-6349-2231
}

\section{Citation Information}

Çakır, Z., \& Altun-Yalçın, S. (2021). The investigation of the effect of Montessori approach-based STEM activities on the problem-solving skills of pre-service preschool teachers. Kuramsal Eğitimbilim Dergisi [Journal of Theoretical Educational Science], 14(2), 93-119. 
Today, economic developments and technological changes have changed the characteristics and competencies expected of people in the 21 st-century competitive world (Çevik \& Abdioğlu, 2018). These qualifications are the skills of being firm against the problems, studying inter-disciplinary, having improved communication skills, creative and problem-solving skills, which is the most significant factor in education. Problem-solving is the planning of the answer to an existed problem, presenting a situation or response to achieve a difficult task, suggesting a probability or showing interest. The most important environment that will help the individual to think original, productive, different and qualified and to become responsible individuals by taking solid steps in the future is education environments (Yuvacı \& Dağlığlu, 2018). Therefore, different and new approaches are needed to educate individuals having these skills in education environments (Şahin, 2013; Yaman \& Yalçın, 2005). It has been supported in several studies that the Montessori approach (Durakoğlu, 2011) and STEM education are effective in getting individuals to acquire problem-solving skills at early ages in the 21st century (Uyanık-Balat \& Günşen, 2017). The easiest way to achieve this is to provide the individual with STEM education with the help of games made in childhood (Uyanık-Balat \& Günşen, 2017). It is suggested that STEM education should be given at a basic level in order to maintain the effectiveness of scientific process skills for individuals (Çepni, 2017). Considering these suggestions, in order to increase the effect and permanence of STEM education to be given in the pre-school period, STEM education applied based on the Montessori approach philosophy, which is of great importance in children's education and school success in this period, will provide a stronger and more effective education (Çakır \& Altun-Yalçın, 2020). These two educational approaches complement each other with the same goals (to raise creative individuals who have 21st-century skills, research, question, analyze, produce, find solutions to problems (Çakır, 2018). Therefore, training of expert teachers who can integrate these trainings by supporting each other and apply them in the pre-school period will be effective in education (Çakır, 2018). In the literature, the importance of bringing up STEM experience to children in the pre-school period and raising individuals who will produce innovative solutions to complex problems in the future and contribute to economic developments is emphasized (Aronin \& Floyd, 2013). However, in our country, sufficient teachers could not be trained at the desired level with this training (Çepni, 2017). The same is true for the Montessori approach in accordance with Montessori principles, preparing new materials and activities suitable for the needs of the developing age and using them properly in the program is an important point that should be adopted in child education (Oğuz \& Köksal-Akyol, 2006). For this reason, in order to apply the Montessori approach in preschool education programs, there should be educators who have absorbed this approach in the school. For this, first of all our teachers who are experts in these fields should be trained. The fact that two approaches are used jointly in the literature and there are almost no studies on prospective teachers reveals the deficiency in this field.

\section{Montessori Approach}

Montessori approach is developed by Maria Montessori. It is based on the child's ability to learn in the best and easiest way through self-application (Yücesan, 2017). The Montessori approach advocates that education is a natural process and the 
child will act according to his inner voice and at his speed so that the child can control himself and achieve permanent learning (Hobbs, 2008). The aim of the Montessori approach is to develop self-confidence, initiative, knowing what you want and applying it, acting independently, problem-solving, making a critical analysis, using creativity skills, concentration, being organized, helping each other, and respecting others (Oğuz \& Köksal-Akyol, 2006). In order to achieve these goals, first of all, to enable the child to live (learn) on his own without forcing the joy of learning; the second is to help perfect the learning mechanism (Özdağ, 2014). Montessori schools are designed in a format that allows children to use the necessary teaching materials and engage in activities related to daily life without the help of adults. In these classrooms, not the areas dominated by adults, but the areas where children are independent and to develop their own control are taken as a basis. Considering all these, all items in Montessori schools or classrooms, especially tables, chairs and cabinets, were prepared according to the height of the children (Arslan, 2016). The main goal here is to enable the child to learn freely by doing, touching, and experiencing. Therefore, it aims to raise qualified and happier individuals for the future (Korkmaz, 2005). Among the most important features, what makes the Montessori approach different from other approaches is that it has its own unique materials developed by the founder of the approach. Montessori materials accommodate the child's sensory areas and daily life exercises. Its applications are based on the principle from simple to difficult and the materials are interesting, natural, vibrant, and colorful. In the Montessori approach, the individual freely creates a product by using his / her own creativity (Yücesan, 2017). In Montessori education classes, trainings consisting of mixed age groups (0-3 and 3-6 ages in 2 groups) are applied, and activities are generally handled individually or in small groups (Hobbs, 2008). The materials used in the activities provide corrective feedback and are grouped into language, senses, culture, mathematics-geometry, art, music, and daily life materials. The Montessori approach positively affects the child physically and mentally; attaches importance to all kinds of senses, movements, and language education of the child; it is an approach that contributes significantly to their physical, social and emotional development (Dereli, 2017).

\section{STEM Education}

STEM is an educational approach in which Science, Technology, Engineering and Mathematics (Mathematics) are given in an integrated manner (Zhou and Wu, 2010). Bybee (2010) describes STEM education as an approach that teaches from preschool to $12^{\text {th }}$ grade by integrating mathematics, science-based engineering, and technology. The process of using STEM education in lessons starts with teaching science and mathematics knowledge. Afterwards, they are given a problem situation where they will use this knowledge and now the engineering design processes begin. As a result of the applied engineering design process, a product emerges. All this process and the resulting product are expressed as technology (Y1ldirım, 2019). The aim of STEM education is to establish interdisciplinary relationships so that learning can be carried out in a holistic approach. STEM education aims to enable students to look at problems from an interdisciplinary perspective and gain knowledge and skills with a holistic education approach (Şahin, Ayar, \& Adigüzel, 2014). To learn the effectiveness of learning by using the principles of age and learning from simple to difficult, theoretical information in STEM education transformed into applications, products, and 
innovative inventions (Milli Eğitim Bakanlığı, 2016). Aslan-Tutak, Akaygün, and Tezsezen (2017) stated in the results of their studies that teacher candidates should be made aware of STEM education before graduating from university, and emphasized that teachers do not have knowledge in areas other than their own fields and that the necessary information should be given in these fields because STEM is an interdisciplinary approach. In Arikan (2018), students who encounter a problem consisting of many variables in real life may not be able to be solved by learning in schools according to a single discipline. Therefore, it was stated that conveying the climate of approaching disciplines as a whole and teamwork with the help of STEM education will contribute to students' solving their problems (Timur, Timur, Yalçınkaya-Önder, \& Küçük, 2020).

\section{Montessori Approach and STEM}

Preschool children are expressed as individuals with enormous potential such as engineers and problem solvers (Hadzigeorgiou, 2002). By an awareness of the importance of early childhood education in the world, including Turkey has been a significant increase in training programs for this area (Dereli, 2017). Materials prepared in accordance with the principles of Montessori approach included in these programs. It provides behaviors and skills that include the willingness and pleasure to work in collaboration, productivity, focusing attention, questioning, creativity, self-confidence, analyzing, responsibility awareness, how to solve a problem, and respect for themselves and others (Durakoğlu, 2011). For STEM education, which has common goals, Chesloff (2013) uses the concepts at the center of STEM; curiosity, analysis, creativity, cooperation, problem-solving and critical thinking. Therefore, he argues that this education should begin in the preschool period in order to gain these skills in the individual and to ensure their permanence. When the literature is examined, two studies have been found among the joint studies of the Montessori approach and STEM. Açıkgöz (2018), in order to determine the extent to which STEM and Montessori approaches can be applied in the preschool education program and what their similar and different aspects are, the views of a total of 14 preschool teachers were examined. Elkin, Sullivan, and Bers (2014) conducted a study on how the robotics curriculum can be applied in Montessori classes. The study was carried out by 1 preschool teacher, who is an expert in the field of Montessori, receiving 3-day training on robotics and applying it to 19 preschool children in his classroom. One of the studies conducted is a qualitative study that only takes an opinion on two approaches. The other is a study that includes only the robotic step of STEM education. In this study, all the steps of STEM education were applied (STEM with simple materials, STEM with types, and robotic coding). In addition, different examples of activities were applied at each step. For example, 4 different robots and their coding were made in the robotic step.

The aim of the present study is to contribute to the development of the problemsolving skills of pre-service preschool teachers with the Montessori approach-based STEM activities. In addition, it is aimed to train teachers to be qualified on STEM Education and Montessori approach, which is one of the new education programs, and to become competent educators who can apply for these education programs in their courses in accordance with the national education curriculum.

Research questions are as the following: 
1. Do STEM activities based on Montessori approach have an effect on pre-school teacher candidates' problem-solving skills?

2. What are the pre-service teachers' feelings and thoughts about activities?

\section{Method}

\section{Research Design}

Within the scope of the research, the descriptive pattern of the mixed method was employed. The mixed-method is collecting both qualitative and quantitative data resources, combining and associating with the purpose of supporting the study results with more than one proof (Baki \& Gökçek, 2012). The descriptive pattern, in which the quantitative analysis is dominant, was employed. In descriptive patterns, the quantitative research is dominant and researchers collect quantitative data and analyse it first. Then, they collect qualitative data to complete, support and refine these data (Büyüköztürk, Kılıç-Çakmak, Akgün, Karadeniz, \& Demirel, 2016). In handling quantitative data, the weak experimental pattern, which is among the experimental research designs, was applied. The basic purpose of needing this method is to measure the effectiveness of any "thing" (a new learning method or a curriculum) and to make suggestions (Büyüköztürk et al., 2016). The single group pre-test, post-test design was created to measure the problem-solving skills of the group in the study.

\section{Study Group}

The research was carried out with 50 teacher candidates studying in the 3rd grade in the pre-school department in a university of a medium-sized city in Eastern Anatolia. Easily accessible sampling model is used. 15 of the group are boys and 35 are girls. The study was implemented under the name of Preschool Science Education course. In the study, the volunteering of the candidates was taken as a basis in the survey applications. In addition, while determining the group, it was taken as a basis that they had not received any previous training in these areas.

\section{Data Collection Tools}

In the study, Problem Solving Scale developed by Heppner and Petersen (1982) and adapted to Turkish for the first time by Taylan (1990) was used to determine the problem-solving skills of prospective teachers in the sample group. The problemsolving scale consists of 35 items that describe how individuals react to their problems in their personal and daily lives and how they react (Kaya, 2010). On the scale, there are 6 sub-dimensions: impetuous style, thinking style, evaluative approach, self-confident, planned approach, and avoidant approach. The reverse items in the scale are items 1, 2, 3, 4, 11, 13, 14, 15, 17, 21, 25, 26, 30 and 34. The Cronbach Alpha coefficient of the scale was found to be .79 .

In collecting qualitative data in the study, a semi-structured interview form consisting of 10 open-ended questions prepared in writing by the researcher for problem-solving skills was used. The purpose of the questions is to determine the opinions, feelings and thoughts of pre-school teacher candidates about the activities carried out in parallel with the quantitative questionnaires. In order to ensure validity, all items of the problem-solving scale were taken as the basis and analyzed in accordance with the research purpose. In addition, these questions were prepared in 
order to determine how and in what direction the development of the problem-solving skills of the candidates, different perspectives and social communication skills of the activities performed during the process. The comprehensibility and suitability of the questions prepared were examined by 3 different experts, and then finalized and applied to 15 volunteers at the end of the process. The interviews were recorded and transcribed and analyzed by the researcher. Each question is included in the results section under the heading of table analysis. The questions are given below.

1. The questions related to opinions of the pre-service teachers are "Did these activities change your perceptions of problem-solving? If yes, can you explain with an example?"

2. The questions related to opinions of the pre-service teachers are "How did the Montessori approach-based STEM activities influence your thoughts towards the problems you encountered?"

3. The questions related to opinions of the pre-service teachers are "Were you able to reach a common conclusion in solving problems within the group? How did you do this? What way did you follow?"

4. The questions related to opinions of the pre-service teachers are "Did you encounter any problems while doing these activities? If yes, how did you solve the problems you encountered?"

5. The questions related to opinions of the pre-service teachers are "What way do you follow in case of problems (during the event) you encounter?"

6. The questions related to opinions of the pre-service teachers are "What did you feel when you could not get the result in any event? Did you think why you could not reach? Did you try to find a solution? How?"

7. The questions related to opinions of the pre-service teachers are "Did you find solutions to the problems in the activities? What changes occurredd in your thoughts and studies when you realised that you had reached the right answer?"

8. The questions related to opinions of the pre-service teachers are "Could you tell us about the ways to solve the problem situations you encounter in the activities?"

9. "Can you anticipate the problems you may encounter while doing other activities yourself after these activities?"

10. The questions related to opinions of the pre-service teachers are "Do you still try to find new ways, even if you know that you cannot reach the conclusion about a problem you encounter?"

\section{Process}

For the Montessori approach-based STEM activities, which will be applied to 50 pre-school teacher candidates for 14 weeks, the relevant literature was first scanned. Activities in line with the results; care has been taken to ensure that STEM education and Montessori approach contain the basic features and common goals. For example, the ability of teacher candidates to integrate them with different fields by using the knowledge of their own fields (the dimension of STEM fields integration) and the excitement that they can create new products in line with the purpose specified in these 
areas (the dimension of creating products freely using the individual's own creativity of the Montessori approach), to be used in their professional life and individual development, attention has been paid to having the qualifications to use its experience and knowledge to solve problems. If it is stated how the STEM and Montessori approach is integrated into the activities; the materials in the Montessori approach applications are interesting, vibrant and colorful. STEM materials also contain a level encountered in daily life that can attract the attention of the child (plastic bottle, motor, rope, colored binding cables, cap, plastic cup, etc.). Montessori materials accommodate the individual's sensory areas and daily life exercises. Similarly, while selecting STEM materials, it includes the sensory field and subjects that can be seen in daily life by making, living, touching. Both approaches contain the characteristic of going from simple to difficult. In addition, individuals were enabled to solve the problem with their own ideas without any intervention in case of making mistakes in the activities. There are 14 activities, and the materials used are composed of materials that will include different application areas. These are, respectively, from the recycling of simple materials that can be found in all areas of daily life (for example, discarded plastic bottles and lids, straws, plastic cups, cardboard boxes, insulating electrical cables, tin coke boxes, etc.), type (made of starch and colored with food dyes) they are small sponges in the form of a cylindrical, wetted special cloths are easily glued with each other by touching them and the desired design is shaped) and robotic-coding design legos. In this process, it was tried to contribute to the development of the problemsolving skills of the teacher candidates, to establish a relationship between the information they acquired and the situations they encountered in daily life, and to create their own products by building new things. After setting up groups of no more than 4 people, firstly, the short and required level of theoretical information about how to do about the activity of that week (for example; required mathematics and science information, showing the figure drawings of the determined activity) were introduced and the necessary materials were introduced. In the events, activities consisting of simple materials, robotic coding with legos and type (small, colored, cylindrical spongelike materials prepared from corn starch for preschoolers, where designs are created by sticking together when wetted) studies were done. In applications made for these purposes, for example, the subject of rain formation and its stages, including science and mathematics, was given to the candidate. The candidates were asked to create a product that is entirely up to their creativity by the group in line with the materials and time given. Later, as an example of those made with simple materials, in the activity named "energetic glass", a circuit institution from the candidates, engineering design, using mathematical measurements to keep balance and a robot using daily materials such as colored pencils and pet glasses has been asked to design. Again with the given legos, the group was asked to design the machines in an amusement park that they encounter in daily life and how these machines work was taught by giving coding training in the computer environment. The coding activities part covers STEM-based robotics activities. For example, they have created activities such as a washing machine, traffic light, carousel with STEM engineered and made STEM-based robotic applications by coding these designs on the computer. In the twelve weeks of 14 weeks, they were asked to create products within the scope of the topics determined by the experts. In the remaining 2 weeks, the candidates were asked to create products within the scope of the topics and materials determined entirely. For example, a group 
presented the concepts of number from the types by integrating the stages of the butterfly with the stages of formation, by narrating the design they created.

Table 1

STEM Activities Based on Montessori Approach

\begin{tabular}{cl}
\hline Weeks & Event names \\
\hline 1 & Balloon car \\
2 & Parachute making \\
3 & Traffic light (from a can of coke) \\
4 & Mousetrap car \\
5 & Non-knockdown CD \\
6 & Remote control snake \\
7 & Energetic glass \\
8 & Carousel robot construction (design and robotic coding) \\
9 & Traffic light (design and robotic coding) \\
10 & Washing machine (design and robotic coding) \\
11 & Sensor door (design and robotic coding) \\
12 & Type studies \\
13 & $\begin{array}{l}\text { Activity presentations prepared by the student candidates (STEM activity } \\
\text { presentations prepared based on the Montessori approach philosophy by leaving } \\
\text { the subject selection to the candidates.) }\end{array}$ \\
& $\begin{array}{l}\text { Activity presentations prepared by the student candidates (STEM activity } \\
\text { presentations prepared based on the Montessori approach philosophy by leaving } \\
\text { the subject selection to the candidates.) }\end{array}$ \\
\hline
\end{tabular}

\section{Data Analysis}

The quantitative data gathered as a result of the study were analyzed with the statistical methods. In the analysis of these data, In order to determine any statistical method in the analysis of these data, considering the histogram graphs and skew coefficient of all measurements, the compliance of the values with the normality assumption was checked with the Kolmogorov - Smirnov test (the sample was taken into account because the sample number is over 30) in order to determine whether the data shows normal distribution or not $(p>.05)$. The graphs and values emerged to indicate that the data show normal distribution. Paired samples t-test was applied to determine whether there was a significant difference between the problem-solving scores in the sample group pretest and posttest results. In the paired samples t-test, pre and post-test averages are compared on the same sample group (Can, 2016).

Qualitative data were subjected to content analysis. In these analysis methods, codes and relevant categories are created from the interviews made by the researcher. In the content analysis, the data were analyzed in four stages: coding the data, finding the categories, organizing-defining the codes and themes, and interpreting the findings (Yıldırım \& Şimşek, 2008). Interviews were made with 15 people. More than one code 
was created in some versions of some of the students. The interview data were recorded, transformed into text, and analyzed in accordance with the stages of content analysis. The codes and categories created in the validity and reliability dimension of the data analysis were analyzed by 4 different experts and the results were combined.

The equation $\mathrm{P}=(\mathrm{Na} \times 100) /(\mathrm{Na}+\mathrm{Nd})(\mathrm{P}$ : percentage of agreement, $\mathrm{Na}$ : amount of agreement, $\mathrm{Nd}$ : amount of disagreement) stated by Miles and Huberman (1994) was used. The percentage of agreement calculated by the researchers was found to be $75 \%$. It was stated by Yıldırım and Şimşek (2008) that when the agreement percentage in the reliability calculation is $70 \%$, it can be assumed that the reliability percentage has been reached.

\section{Ethics Committee Information}

Erzincan University Human Rights Ethics Committee is a study dated 30.11.2017 and numbered 09/09. In the study, volunteer individuals in the sample group selected to collect data were informed about the subject by signing a consent form. None of the actions against the Scientific Research and Publication Ethics have been carried out and all the rules in the Higher Education Institutions Scientific Research and Publication Ethics Directive have been followed.

\section{Findings}

The quantitative and qualitative findings gathered in the research are presented in tables with their interpretations below.

The paired samples t-test results for the pre and post-test scores of the problemsolving skills of the pre-service teachers are presented in Table 2. The paired samples ttest was applied to determine the effect of activities on the problem-solving skills of the pre-service teachers and to find out the significant difference between the pretestposttest scores. In the results of the test, it was observed that there was a significant difference between the scoring average (pre-test=139.20) before the application and the average (post-test $=151.10)$ after the application $(t(49)=-3.383, p<.05)$. Thanks to this significant difference, it can be claimed that the education given developed the problemsolving skills of the preschool pre-service teachers. In order to analyze the qualitative data, each question is analyzed separately and a table is created and interpreted below.

Table 2

The Paired Samples T-Test Results Related to Problem-Solving Skills.

\begin{tabular}{ccccccc}
\hline Measurements & $n$ & $\bar{X}$ & ss & $t$ & $s d$ & $p$ \\
\hline Pre-test & 50 & 139.20 & 18.67 & & & \\
Post-test & 50 & 151.10 & 19.51 & & & \\
\hline$p<.05$ & & & & &
\end{tabular}


Table 3

Paired Samples T-Test Results for Sub-Dimensions of the Problem Solving Skill Scale

\begin{tabular}{|c|c|c|c|c|c|}
\hline Bottom Dimension Measurements & $N$ & $\bar{X}$ & Ss & $t$ & $p$ \\
\hline Impetuous style Pre-test & 44 & 34.95 & 5.96 & -4.513 & .000 \\
\hline Impetuous style Post-test & 44 & 40.63 & 6.30 & & \\
\hline Thinking style Pre-test & 48 & 23.56 & 3.75 & -.443 & .659 \\
\hline Thinking style Post-test & 48 & 23.85 & 4.0 & & \\
\hline Evaluative approach Pre-test & 48 & 27.50 & 4.64 & -1.174 & .246 \\
\hline Evaluative approach Post-test & 48 & 28.54 & 5.31 & & \\
\hline Self-confident Pre-test & 50 & 19.48 & 3.12 & .061 & .951 \\
\hline Self-confident Post-test & 50 & 19.52 & 3.48 & & \\
\hline Planned approach Pre-test & 49 & 13.42 & 3.00 & -2.643 & .011 \\
\hline Planned approach Post-test & 49 & 14.83 & 2.0 & & \\
\hline Avoidant approach Pre-test & 48 & 18.31 & 3.45 & -.891 & .417 \\
\hline Avoidant approach Post-test & 48 & 18.89 & 3.82 & & \\
\hline
\end{tabular}

Lower dimensions (1: Impetuous style, 2: Thinking style, 3: Evaluative approach, 4: Self-confident, 5: Planned approach, 6: Avoidant approach)

Paired samples t-test results for detecting the difference between pre-test and post-test scores of 6 sub-dimensions of the pre-service teachers' problem-solving skills scale are shown in Table 3. In the results of the test, there was a statistically significant difference in the 1st and 2nd sub-dimensions $(p<.05)$, while no difference was found in the 2, 3, 4, and 6th dimensions ( $p>.05)$.

Table 4

The Opinions of the Pre-Service Teachers Related to the Question "Did These Activities Change Your Perceptions of Problem-Solving? If Yes, Can You Explain With An Example?"

\begin{tabular}{lcc}
\hline Category & Code Name & Frequency $(f)$ \\
\hline \multirow{3}{*}{ Method and Technique } & Trial and error & 3 \\
& Scientific overview & 3 \\
& Different solutions & 2 \\
& Problem-solving & 1 \\
\hline \multirow{2}{*}{ Individual Qualification } & Clearance of prejudices & 4 \\
& Dealing with the problem & 3 \\
\hline Other & Self-confidence & 2 \\
\hline Total & & 4 \\
\hline
\end{tabular}


In Table 4, the answers of the teacher candidates regarding the question are given and 3 separate categories have been created. In the category of method and technique; the statements about the positive thoughts and problem-solving methods provided in the perceptions of the pre-service teachers in solving a problem after the activities were included. The candidates stated that they did not deal with a problem (especially about science) before the training, even if they did not find it, they stopped. However, after this training, they constantly learned to develop different perspectives on the problem, tried by making trial and error, found new ways, learned from their mistakes and succeeded in reaching a solution by offering different solutions to the problem that will arise in the next event, and they learned to look at the problems they encountered from a more scientific perspective have done.

In the individual qualification category; Statements containing the contribution of positive effects on candidates' perceptions in solving a problem after the activities to their competencies were included. In this category, the candidates included opinions stating that their prejudices such as not being able to do or not being able to solve any problem were demolished and their self-confidence increased in problem-solving, each activity they made facilitated the next one and that they could overcome the problems.

In the category of 'other', some pre-service teachers stated that they did not have a very in-depth effect on their perceptions about the problem as they found the training given short.

Some of the preservice teachers' views on the question are given below.

"...We are purified in our prejudices. We learned that there is nothing we cannot do..."

“... Sure. For example, the teacher liked the binding system we use in the traffic light event, which led me to create new roads. It allowed me to gain different perspectives..."

“... Provided. While I used to find a solution to a problem, now I wonder if I can find different solutions..."

In Table 5, the answers of the teacher candidates regarding the question are given and 6 separate categories have been created. In the learning category; pre-service teachers teach that the activities teach how to find different solutions and perspectives for the solution of a problem, to deal with different aspects of the problem, to reach the solution of the problem carefully, patiently, by making mistakes, step by step, to learn by living by doing one-to-one and to use concrete expressions suitable for children they stated. 
Table 5

The Opinions of the Pre-Service Teachers Related to the Question "How Did the Montessori Approach-Based STEM Activities Influence Your Thoughts Towards the Problems You Encountered?"

\begin{tabular}{|c|c|c|}
\hline Category & Code Name & Frequency $(f)$ \\
\hline \multirow{5}{*}{ Learning } & Different perspective & 5 \\
\hline & Be patient & 3 \\
\hline & By doing & 2 \\
\hline & Use of electronic tools & 1 \\
\hline & Embodying abstract issues & 1 \\
\hline \multirow{3}{*}{ Thinking Skills } & Mental activities & 8 \\
\hline & Abstract and versatile & 5 \\
\hline & Generating hypotheses & 1 \\
\hline \multirow{4}{*}{$\begin{array}{l}\text { In Terms of Social } \\
\text { Perspectives }\end{array}$} & Fixing social relationships & 3 \\
\hline & Cooperation & 2 \\
\hline & Sharing & 1 \\
\hline & Don't listen & 1 \\
\hline \multirow{2}{*}{$\begin{array}{l}\text { In Terms of Education } \\
\text { Opportunities }\end{array}$} & Preschool period & 2 \\
\hline & Career & 1 \\
\hline \multirow{4}{*}{$\begin{array}{l}\text { Product Creation } \\
\text { Methods }\end{array}$} & By trying and wrong & 2 \\
\hline & Following the stages & 2 \\
\hline & Going from part to whole & 1 \\
\hline & Putting the problem on the versatile table & 1 \\
\hline \multirow{3}{*}{ Awareness Level } & Noticing the situation & 4 \\
\hline & Helps in solving problemsThe beauty of education & 3 \\
\hline & & 1 \\
\hline Total & & 50 \\
\hline
\end{tabular}

In the category of thinking skills; the candidates stated that various thinking skills for any problem were developed after the activities. In other words, they stated that their mental thinking activities developed in the face of a problem situation, they thought more creatively and critically, they could think abstractly and put forward many hypotheses in the face of the problem, and they were able to use their versatile thinking skills to create the product in the light of these hypotheses.

In the category of social aspects; they stated that the activities performed positively affect their social skills, for example, they reached the result more easily by making collaborative practices in the face of the problem. They also stated that thanks to these activities, they listened patiently and respectfully to each other, shared information and overcome the problem in solidarity because they were doing as a group to solve a problem, and their negative thoughts towards their groupmates decreased (their social relations improved).

In the category of educational opportunities; the candidates stated that the Montessori approach-based STEM activities are suitable for preschool children and 
teachers can easily apply these activities in their professional lives. They also talked about the importance of providing the child the opportunity to find the problem that arises in any activity.

In the category of product creation methods; the candidates talked about the methods they have used to reveal the product against the problems during the activities. They stated that they gained experience from the mistakes they made for the problems they made, that they progressed carefully while making the product, that they discussed the problem from many aspects and strived for its solution, reached from the piece to the whole and made very good products by trial and error.

In the awareness category, the candidates talked about the beauty of the activities, the benefits they provided to them, and their awareness of a situation.

They stated that it helps them develop their ability to create different solutions in the solution of a problem and design remarkable products.

Some of the preservice teachers' views on the question are given below.

“... I didn't know about STEM. Especially that it can be applied in the pre-school period.. then we found and started to use examples that we learned in our presentations..."

"...It was a very good education. It helps us a lot in problem-solving. Before we started an activity, we produced something about it, then we posed a problem. Then we got it resolved. It helped a lot in these matters..."

“... Montessori is already an education in itself. Once, it offers children learning by doing. Our aim is to find the problem for the child and find the result himself. It activates the thoughts and mental activities of the child as it gives this opportunity..."

Table 6

The Opinions of the Pre-Service Teachers Related to the Question "Were You Able to Reach A Common Conclusion in Solving Problems Within the Group? How Did You Do This? What Way Did You Follow?"

\begin{tabular}{lcc}
\hline Category & Code Name & Frequency $(f)$ \\
\hline \multirow{3}{*}{ Social Competence } & Collaborative work & 7 \\
& Joint decision making & 6 \\
& Business departments & 6 \\
\hline \multirow{3}{*}{ Mental Achievements } & Achievement & 6 \\
& Joint solution & 5 \\
& Respect for ideas & 4 \\
& Presenting ideas & 4 \\
& Don't try ideas & 2 \\
& Logic & 2 \\
& Recognizing mistakes & 1 \\
\hline Behaviour & Don't put effort & 1 \\
& Not give up & 1 \\
& Calm & 1 \\
\hline Total & Getting information & 1 \\
\hline
\end{tabular}


Table 6 includes the answers of the teacher candidates regarding the question and 3 separate categories were created. In the social competence category; the teacher candidates are able to make group decisions in solving the problems that arise during the activity, and while doing this, they can work collaboratively, come together as a group to reach common decisions and conclusions, allow the implementation of every opinion put forward, the method they use such as creating a team spirit and the behaviors they pay attention to.

In the category of mental acquisitions; it includes expressions about what the ideas and methods they produce in solving the problem mentally bring. The preservice teachers stated that they offered everyone their ideas to reach the solution of the problem, they cared and tried all the ideas, they found the mistakes as a result of the experiments, and they achieved success in the solution by combining the common decision taken by the group with the ideas found to be correct and logical.

In the behavior category, the behaviors of the teacher candidates during the implementation phase of the common decisions they take to reach the result are included. Statements were included stating that each member of the group made an effort to achieve a result, that they acquired information focused on revealing the product, that they maintained their calmness in case of negative results, and they made trials until they reached the result again and again, and that they wanted the product to be satisfied for every member of the group.

Some of the preservice teachers' views on the question are given below.

“... In the early days, I was saying everyone should listen to my opinion. But after listening to me, I saw that we got the wrong conclusions. Later, I learned to act with the group and make joint decisions. Because sometimes someone else can see something that I do not see..."

“...There was teamwork. We used to divide work. We would try and respect everyone's opinion among ourselves and we took whatever happened..."

“... There were some difficulties with different people at first, but this was a group work and somehow we had to make sacrifices and meet common results and we succeeded..."

“...We always decided as a group. Everyone has come up with their minds. We did it according to who got the most votes..."

Table 7 includes the answers of the teacher candidates regarding the question and 3 separate categories were created. In the problem-solving category; candidates applied for expert help to solve the problems that arise in the activities (for example, lack of material, lack of theoretical knowledge, inability to reach a result), they tried different ways by taking different opinions of the group members, they tried to notice their mistakes by doing the activity again and again, that they joined together as a group, helped them in their own field. They stated that they made use of the knowledge and science-mathematics knowledge, followed the instructions in the guides given in some activities and reached a solution by using trial and error methods considering different possibilities. 
Table 7

The Opinions of the Pre-Service Teachers Related to the Question "Did You Encounter Any Problems While Doing These Activities? If Yes, How Did You Solve the Problems You Encountered?"

\begin{tabular}{lcc}
\hline Category & Code Name & Frequency $(f)$ \\
\hline & Group collaboration & 5 \\
& Expert assistance & 4 \\
Problem Solving & Try different ways & 4 \\
& Information & 3 \\
& Guidelines & 1 \\
& Correcting mistakes & 1 \\
\hline \multirow{3}{*}{ Attitudes Towards Problem } & Be patient & 2 \\
& Competition ambition & 2 \\
& Competition pleasure & 1 \\
Problems & Strain & 1 \\
& Inability to place materials & 2 \\
Total & Lack of material & 1 \\
\hline
\end{tabular}

In the category of attitudes towards problem; statements stating the candidates' attitudes towards the problems they encountered were included. They stated that even if they have difficulties in the face of problems, they never give up with the ambition to reach results and compete, they tried hard again and again patiently, and they did it by enjoying the excitement of the competition.

In the category of problems, the problems that the teacher candidates encountered in the activities were included. These problems are the lack of material and the difficulties they experience in material placement.

Some of the preservice teachers' views on the question are given below.

"...We met. We solved them by helping each other. We found it by trying different ways..."

"...Yes. For example, when we were making materials, we did it first in the balloon car event, but the car was not driving fast, we used science knowledge in this problem. In other words, we used smaller and lighter materials due to speed and usage. In this event, we learned that the more we reduce the friction, the faster it goes..."

“...I had difficulties in making materials with some simple materials, but since there are competitions or something that adds pleasure to the lesson, we quickly resolved the problem as a group..."

Table 8 includes the answers of the teacher candidates regarding the question and 2 separate categories were created. In the category of problem-solving methods; the methods applied by the candidates to solve the problems they experienced during the activity were mentioned. In other words, they first determine the problem situation in the face of existing problems and if there is missing material in the activity, they remove the missing part by making different designs with other materials in their possession to provide it, they make a group meeting and distribute work and tasks for the problem, make a literature review or consult expert opinions, statements were included stating that they tried to determine different hypotheses for the solution and tried to determine 
them by trial and error and that they tried to detect the error by looking at the guides and proceeding step by step.

Table 8

The Opinions of the Pre-Service Teachers Related to the Question "What Way Do You Follow in Case of Problems (During the Event) You Encounter?"

\begin{tabular}{lcc}
\hline Category & Code Name & Frequency $(f)$ \\
\hline & Expert opinions & 9 \\
Group meeting & 7 \\
Work sharing & 4 \\
& Elimination of missing materials & 3 \\
Groblem Solving Methods & Generating hypotheses & 3 \\
& Guides & 2 \\
& Retries & 2 \\
& Literature review & 1 \\
& Step by step progress & 1 \\
& Identifying the problem & 1 \\
& Understanding the problem & 1 \\
& Do not ask me question & 1 \\
\hline Skill-Knowledge & Respect for ideas & 7 \\
& Brainstorming & 5 \\
& Hand skill & 1 \\
& Area information & 1 \\
\hline Total & Designing different parts & 1 \\
\hline
\end{tabular}

In the knowledge-skill category; they talked about the methods used by preservice teachers in problem-solving and the knowledge-skills they gained as a result. Individuals stated that they gained the skills of generating different ideas, designing different pieces by brainstorming as a group against the problem, gained the skills to respect each other's views, and again, in order to reach a solution, they consulted the ideas of their friends, whom they trusted in their field knowledge and manual skills.

Some of the preservice teachers' views on the question are given below.

"...With divisions of labor within the group. After the first weeks, our problems decreased as we got to know each other. As a group, we listened to everyone's ideas and distributed tasks..."

“...First I determine the problem. Then I proceed step by step. STEM taught me this already. I grasp the problem, proceed step by step, and reach the result..."

"...In our group friends, we turned to everyone according to their own hand skills and knowledge in the field. For example, one of them collected materials, the other detected the missing materials, and the other produced a solution to the problem by using field information..."

In Table 9, the answers of the teacher candidates regarding the question are given and 2 separate categories have been created. In the attitude category, the attitudes that include the feelings of the candidates when they cannot produce products while performing the activities are included. These; when candidates do not reach the result, 
they stated that they were depressed, they were very upset, they were angry, they always continue with the ambition to reach a result, they felt bad and they had a hard time reaching a solution. When they reached the result, they stated that they had good feelings.

Table 9

The Opinions of the Pre-Service Teachers Related to the Question "What Did You Feel When You Could Not Get the Result in Any Event? Did You Think Why You Could Not Reach? Did You Try to Find A Solution? How?"

\begin{tabular}{lcc}
\hline Category & Code Name & Frequency $(f)$ \\
\hline & Do not be sad & 3 \\
\multirow{3}{*}{ Attitude } & Getting angry & 3 \\
& Strain & 2 \\
& Good feelings & 2 \\
& Ambition & 1 \\
\hline \multirow{2}{*}{ Creating Solutions } & Solidarity & 5 \\
& Learning by doing & 4 \\
& Stage Review & 4 \\
Total & Exchange of ideas & 2 \\
\hline
\end{tabular}

In the category of generating solutions, they stated the solutions that the teacher candidates applied when they could not reach the result. These; they stated that they received help from experts, senior classmates, groupmates and friends in other groups who were knowledgeable about the subject, they tried to find the existing mistakes by constantly starting the construction of the activity, they tried to find the existing mistakes, they tried different ways by exchanging ideas within the group, and they found solutions by correcting the mistakes.

Some of the preservice teachers' views on the question are given below.

“...I was very sad when you couldn't. Of course, I thought about the solution. I disassembled it and did it all over again. I reviewed the stages again..."

“...We had a hard time when we couldn't reach a result. Then we went back over and over again. We corrected our mistakes and came to a conclusion, which was a very good feeling. Even if we were forced, it was beautiful. Seeing our own mistakes and correcting it ourselves, trying again, exchanging ideas on our mistakes as a group...”

“...I got so angry when I couldn't reach it. I said I should definitely arrive. Then I thought and tried to find different ways and reached..."

The answers of the teacher candidates related to the question are given in Table 10 and 2 separate categories have been created. In the readiness category; the candidates stated that they have feelings that increase success such as happiness and selfconfidence that comes from reaching the right results by producing solutions to the problems that occur and that all these feelings positively affect their level of readiness for the next event so that they expect the next event with even more enthusiasm, determination, curiosity, and excitement. They also stated that they enjoyed what they did and that all this motivated them. 
Table 10

The Opinions of the Pre-Service Teachers Related to the Question "Did You Find Solutions to the Problems in The Activities? What Changes Occurred in Your Thoughts And Studies When You Realised That You Had Reached the Right Answer?"

\begin{tabular}{lcc}
\hline Category & Code Name & Frequency $(f)$ \\
\hline & Don't make you happy & 7 \\
Readiness & Self-confidence & 4 \\
& Excitement & 2 \\
& Success & 2 \\
& Perseverance & 2 \\
Attitude & Finding a solution & 9 \\
& Request to move on to the next step & 4 \\
& Product design & 3 \\
Total & Active participation & 2 \\
\hline
\end{tabular}

In the attitude category; similar to the statements in the readiness category, as the candidates overcome the problems, everyone in the group actively participates in the activity against another problem, they want to find new things in constant search, they want to design different ideas and products, develop solutions, desire to do their best and they stated that they constantly strive to move on to the next stage.

Some of the preservice teachers' views on the question are given below.

“... Of course. We set out on a road and finally reached the right path, and this increases people's enthusiasm and makes them happy. Most importantly, you say 'I did it'..."

“...Yes. It excites me to have a lot of effort and to move forward. And it motivates the event to be held next week..."

“...Yes. I tasted the sense of success. For example, I am building a machine; light is on, it sounds and moves. I had the pleasure of designing something. This also increased my selfconfidence towards the work..."

"...When one finds the truth, one starts to study other ideas. In other words, I come up with different ideas such as I mean this is happening in this and if I combine this and this, I can reach this conclusion..."

Table 11 includes the answers of the teacher candidates regarding the question and a single category was created. In this category; the methods applied for the solution of the problems arising during the activities were mentioned. The candidates applied to the science field for the solution of the problem that emerged, if there were any missing materials, they closed the gap by designing that material from other materials themselves, they proceeded by trying the group views put forward and correcting the mistakes, they tried to influence the juries who would evaluate the product by keeping the verbal defense of the designs strong, they stated that they consulted experts and checked the stages by looking at the given guides. 
Table 11

The Opinions of the Pre-Service Teachers Related to the Question "Could You Tell Us About the Ways to Solve the Problem Situations You Encounter in the Activities?"

\begin{tabular}{lcc}
\hline Category & Code Name & Frequency $(f)$ \\
\hline & Science knowledge & 4 \\
& Missing part design & 2 \\
Troubleshooting Ways & Group comments & 1 \\
& Trial and error way & 1 \\
& Oral defense & 1 \\
\hline Total & Expert opinions & 1 \\
\hline
\end{tabular}

Some of the pre-service teachers' views on the question are given below.

"...For example, there was no wheel on the balloon car. Everyone had bought the wheel before, it was not up to us. That's why we couldn't maintain balance, so the air was wasted. That's why we designed wheels that can enter thereby combining two different circle shapes. So we solved the problem..."

"... For example, we made the way for it to go fast in the car event, we first made it for a long time and then looked at it. We broke it and shortened it and solved the situation where it goes faster...”

“...We discussed the problem with our group friends. Then we looked at the guides, checked the stages over and over and we did it...."

Table 12

"Can You Anticipate the Problems You May Encounter While Doing Other Activities Yourself After These Activities?"

\begin{tabular}{lcc}
\hline Category & Code Name & Frequency $(f)$ \\
\hline & Experience & 4 \\
\multirow{2}{*}{ Critical Thinking Tendency } & Sensing danger & 3 \\
& Measure-prevention & 3 \\
& Enough information & 3 \\
& Don't be fast & 1 \\
\hline \multirow{2}{*}{ Other } & Partially & 3 \\
& Distribution of work & 1 \\
& Inability to guess & 1 \\
\hline Total & & 19 \\
\hline
\end{tabular}

Table 12 includes the answers of the teacher candidates regarding the question and 2 separate categories were created. In the category of critical thinking disposition; they stated that the candidates had the ability to anticipate the dangers of a problem they will encounter as a result of the activities given, in other words, critical thinking disposition behaviors. Having enough information about these trends and how they emerge, to have enough information about the activities they will do, to be able to 
anticipate the danger in advance and take the necessary precautions, and to make preparations for the next steps, to learn from their mistakes in their activities, that is, to be able to move faster to the next by experience and now a lot of information is settled in their minds.

In the other category, only one of the candidates stated in his answer to the question that he could not sense the problem beforehand, but he made sense when this problem happened to him. On the other hand, 3 people stated that they could partially sense the problem and take measures, depending on the type of problems that may arise. On the other hand, the job distribution code stated that individuals overcame the problem by making divisions of work according to the status of group members among themselves.

Some of the preservice teachers' views on the question are given below.

“...We know what to do, when the professor gives the draft, we look at it first and, as an estimate, we do what is necessary immediately... We do business segments, for example, to be fast..."

“...Of course. I made this mistake here before, but I am preparing myself for the next one, in order not to make the same mistake again..."

"...Yes. This situation is about experience. So, our prediction increased with this training. We are more cautious against problems so..."

Table 13

The Opinions of the Pre-Service Teachers Related to the Question "Do You Still Try to Find New Ways, Even If You Know That You Cannot Reach the Conclusion About A Problem You Encounter?"

\begin{tabular}{lcc}
\hline Category & Code Name & Frequency $(f)$ \\
\hline & Struggle & 9 \\
& Don't try to the end & 6 \\
Method & Verbal defense & 3 \\
& Claim & 4 \\
& Group supports & 2 \\
& The quest & 2 \\
& Move forward & 2 \\
\hline \multirow{3}{*}{ Feeling - Thought } & Disagreement & 1 \\
& Don't hope & 2 \\
\hline Total & Don't be frustrated & 2 \\
\hline
\end{tabular}

In Table 13, the answers of the teacher candidates regarding the question are given and 2 separate categories have been created. In Method - Method category; the candidates talked about the efforts and methods they have made to reach the result for the solution of the problem. All of the candidates stated that they had a feeling of constantly producing new things and trying to achieve a solution in the face of the problem. For this, the group members stated that they constantly support each other, try 
to produce different ways, use their time until the last minute and do their best, conduct specific theoretical researches, and always want to move their products forward, that is, to a higher level.

In the Emotion-Thought category, codes indicating the pre-service teachers' feelings and thoughts when they could not reach a solution in the face of a problem were included. In the face of this situation, the candidates; first of all, even if they were disappointed, they always kept their hopes alive and they tried to find different ways again without giving up, one person stated that after trying all the ways, he started to get bored and left the solution of the problem to his other friends.

Some of the preservice teachers' views on the question are given below.

“...Even if we could not reach a good result, we thought of new ways. Our material was not very good, but we said that if we defend it well, we can succeed and we won the second place..."

“...I tried to the end. I tried until the last drop. But I think these are about supporting each other as a group. If only one person did, he would surely give up. We have given each other a lot of support so that we can do it; they did it, we gasped to each other why we couldn't do it and we achieved good results..."

“...We have already done this with this training. Our teacher did not like what we did at first. We were disappointed, but we did not despair, we added something to it and presented it and succeeded in being the first..."

\section{Result and Discussion}

It was determined at the end of the quantitative analysis that STEM activities based on the Montessori approach improved the problem-solving skills of pre-school teacher candidates and it was observed that this result was supported by the qualitative analysis. It can be interpreted that the activities carried out in line with the analysis results were effective in developing the problem-solving skills of prospective teachers. It supports the results in the literature that STEM education improves the problemsolving skills of the individual. Sungur-Gül and Marulcu (2014) stated in their study results that teachers, an engineering-design-based course would commonly improve students' psychomotor, problem-solving and social thinking skills. Elkin et al. (2014) conducted research on how to apply the robotics curriculum in early childhood Montessori classes. In the results of the study, they prepared a report that includes robotics education can be effective in preschool and how it should be integrated into lessons. Strong (2013) stated in his study that STEM education improves scientific process skills. Sullivan (2008) stated that robotics and science literacy education contributed to the development of students' thinking and scientific process skills. In Kaya (2010) and Kökdemir (2003) studies, STEM education included ideas and conclusions stating that it will provide an interdisciplinary perspective, improve problem-solving, engineering design and creativity skills, and increase students' interest-motivation towards courses.

The qualitative analysis results collected with the semi-structured interview forms of the study also appeared to support the quantitative result, that is, the activities developed the problem-solving skills. The candidates stated that they achieved positive changes in their perceptions and skills about problem-solving after the activities. They stated that thanks to the activities, they learned not to give up in the face of problems and to develop different scientific perspectives on the problem with their experience. They stated that their prejudices such as not being able to solve the problem were 
destroyed, their self-confidence increased, their motivation and knowledge (success) towards science lessons increased. In a study supporting the results, Judson (2014) found a significant difference in terms of academic achievement between the STEMapplied experimental group and the non-applied control group as a result of the experimental and control group research on students' academic achievement of STEM applications. Çevik and Abdioğlu (2018) examined the effect of a science camp on 8thgrade students' STEM achievement, science motivation and metacognitive awareness.

As a result, they found that STEM activities significantly increased STEM achievement and that STEM achievement had a high level of correlation with science motivation and metacognitive awareness. Bakırc1 and Kutlu (2018) examined the opinions of science teachers about STEM education. As a result, the teachers stated that STEM education would increase students' interest and motivation towards the course, gain different perspectives and improve their decision-making skills. Y1ldırım (2019) stated in his study, which included the opinions of pre-service science teachers about biomimicry applications in STEM education, that the candidates had different perspectives thanks to the activities and that their motivation increased by producing solutions in the face of problems.

Among the qualitative results of the study, they stated that acting as a group in solving a problem in activities positively affected their social skills and communication skills. The studies of Tarkın-Çelikkıran, and Aydın-Günbatar (2017), which supports the positive results of working as a group in the research; they stated that the teacher candidates who will be trained with STEM activities will be more successful in creating interdisciplinary connections. In addition, they stated that doing STEM practice with group interactions with friends while solving problems was more positive. Akgündüz and Akpinar (2018) stated that in STEM education study results, students gained science and mathematics achievements with STEM applications in preschool education; they found that it developed 21st-century skills such as creativity, critical thinking, collaboration, and communication. In addition, in this study, they stated that STEM education practices developed creativity and communication skills in children, especially during the engineering design cycle, by presenting original ideas and evaluating alternative solutions that emerged from different ideas. Keçecioğlu (2015) researched the effect of Montessori approach on social development skills of the individual compared to normal education and recorded positive results. Ceylan (2014) supports the research results by stating that STEM education improves students' creativity, academic achievement, and problem-solving skills. Koçyiğit and Kayılı (2008) conducted a study to compare the social skills of kindergarten children who received an education with the Montessori approach and received an education with the normal curriculum. According to the results of the study, they stated that kindergarten students studying with the Montessori approach observed that there was a significant difference in social cooperation, social interaction, and social independence subdimension scores from kindergarten students who received education according to the normal curriculum. In the study, teacher candidates stated that doing collective activities in cooperation in the face of a problem leads to a result more easily. Again, thanks to these activities, the candidates stated that they overcame each other with patience and respect, exchange information and overcome in solidarity as they did as a group to solve a problem and that their negative social relations towards their groupmates improved. 
Finally, in the qualitative results of the study, prospective teachers stated their opinions regarding the suitability of STEM activities to preschool children. They stated that these activities can be applied easily due to their remarkable, fun and curious features, and some of them stated that the dimensions of the materials used are suitable for the child's muscle skills, that is, if the safety of the materials such as adhesives is ensured, they will be more suitable for children.

Hartzler's (2000) study, which supports the results, concluded that the mathematics and science activities taught in consideration of engineering design increase the student's interest in the course, desire to learn and succeed, supports the qualitative results of the study. Doppelt, Mehalik, Schunn, Silk, and Krysinski (2008) stated in their study that STEM education has a very important place in increasing students' interest in science, desire to learn, and succeed. Akins and Burghardt (2006) investigated the application of mathematical reasoning in solving a design-related problem in their research with middle and high school students, titled Developing K-12 mathematical understanding through engineering design projects. As a result, they stated that progress was observed in all students' mathematics and science tests, and although there were no significant changes in the scores of some of the students who participated in engineering activities, these students improved their skills in analyzing, explaining, commenting or reasoning about mathematics, science, and technology.

\section{Recommendations}

This study was carried out with the pre-service teachers at the third class of preschool teacher training department of the faculty of education in a state university. New researches to be conducted based on this study can be carried out on different faculties and classes (except for 4th-grade students; the pre-service teachers are not able to focus adequately on activities because they concentrate on the KPSS). This study can be carried out for longer periods. Moreover, the fact that the study took place in a university and was completed within a certain period of pre-school science education course also created a limitation in discussing the effects of the study. Instead of considering the Montessori approach-based STEM applications developed by the researchers in a limited way within the pre-school science education course, it can be recommended to be given to pre-service teachers as a lesson.

\section{Statement of Responsibility}

Zehra Çakır; planning and implementation of activities, analysis, methodology, resources, literature review, formal arrangement, verification, reporting, writing reviewing and inspection. Sema Altun-Yalçın; Determination of problem situation, determination of sample group, determination of activities, planning and implementation of activities, selection and application of data collection tools, verification, analysis. 


\section{References}

Açıkgöz, S. (2018). Fen eğitiminde okulöncesine yönelik yaklaşımlardan STEM ve Montessori yöntemlerinin öğretmen görüşleri doğrultusunda karşılaştırılması (Yüksek lisans tezi). Kastamonu Üniversitesi, Fen Bilimleri Enstitüsü, Kastamonu.

Akgündüz, D., \& Akpınar, B. C. (2018). Okul öncesi eğitiminde fen eğitimi temelinde gerçekleştirilen STEM uygulamalarının öğrenci, öğretmen ve veli açısından değerlendirilmesi. Yaşadıkça Ĕ̆itim, 32(1), 1-26.

Akins, L., \& Burghardt, D. (2006). Work in progress: Improving K-12 mathematics understanding with engineering. Design Projects in Proceeding from the 36th ASEE/IEEE Frontiers in Education Conference, New York: Institute of Electrical and Electronics Engineers.

Arıkan, E. (2018). A theoretical study on STEM education: Proposal of two applications. Journal of Theoretical Educational Science, 11(1), 101-116. https://www.doi.org/10.30831/akukeg.336777.

Aronin, S., \& Floyd, K. K. (2013). Using an iPad in inclusive preschool classrooms to introduce STEM concepts. Teaching Exceptional Children, 45(4), 34-39.

Arslan, E. (2016). Montessori yönteminin anaokulu çocuklarının büyük kas becerilerine etkisinin incelenmesi (Yüksek lisans tezi). Necmettin Erbakan Üniversitesi, Eğitim Bilimleri Enstitüsü, Konya.

Aslan-Tutak, F., Akaygün, S., \& Tezsezen, S. (2017). İşbirlikli FeTeMM (fen, teknoloji, mühendislik, matematik) eğitimi uygulaması: Kimya ve matematik öğretmen adaylarının FeTeMM farkındalıklarının incelenmesi. Hacettepe Üniversitesi Ĕ̈itim Fakültesi Dergisi, 32(4), 794-816. https://www.doi.org/10.16986/HUJE.2017027115.

Bakırcı, H., \& Kutlu, E. (2018). Fen bilimleri öğretmenlerinin FeTeMM yaklaşımı hakkındaki görüşlerinin belirlenmesi. Türk Bilgisayar ve Matematik Eğitimi Dergisi, 9(2), 367-389. https://doi.org/10.16949/turkbilmat.417939

Baki, A., \& Gökçek, T. (2012). Karma yöntem araştırmalarına genel bir bakış. Elektronik Sosyal Bilimler Dergisi, 11(42), 1-21.

Büyüköztürk, Ş., Kılıç-Çakmak, E., Akgün, Ö. E., Karadeniz, Ş., \& Demirel, F. (2016). Bilimsel araştırma yöntemleri (21. baskı). Ankara: Pegem Yayıncılık.

Bybee, R. W. (2010). What is STEM?. Science Education, 329(5995), 996. https://doi.org/10.1126/science.1194998

Can, A. (2016). SPSS ile bilimsel araştırma sürecinde nicel veri analizi (6. baskı). Pegem Akademi.

Ceylan, S. (2014). Ortaokul fen bilimleri dersindeki asitler ve bazlar konusunda fen, teknoloji, mühendislik ve matematik (FeTeMM) yaklaşımı ile ögrretim tasarımı hazırlanmasına yönelik bir çalışma (Yüksek lisans tezi). Bursa Uludă̆ Üniversitesi, Eğitim Bilimleri Enstitüsü, Bursa.

Chesloff, J. D. (2013). Why STEM education must start in early childhood. Education Week, 32(23), 27-32. 
Çakır, Z. (2018). Montessori yaklaşım temelli STEM etkinliklerinin okul öncesi ögretmen adayları üzerindeki etkisinin incelenmesi (Yüksek lisans tezi). Erzincan Binali Yıldırım Üniversitesi, Fen Bilimleri Enstitüsü, Erzincan.

Çakır, Z., \& Altun-Yalçın, S. (2020). Pre-school teacher candidates' views on STEM applications based on Montessori approach. Turkish Online Journal of Qualitative Inquiry, 11(3), 344-368. https://doi.org/10.17569/tojqi.xxxxx

Çepni, S. (2017). Kuramdan Uygulamaya STEM+A+E Eğitimi. 1. Bask1, Pegem Akademi Yayıncılık, Ankara.

Çevik, M., \& Abdioğlu, C. (2018). Bir bilim kampının 8. sınıf öğrencilerinin STEM başarılarına, fen motivasyonlarına ve üstbilişsel farkındalıklarına etkisinin incelenmesi. Insan ve Toplum Bilimleri Araştırmaları Dergisi, 7(5), 304-327.

Dereli, E. (2017). Montessori eğitim programının çocukların psikososyal gelişimlerine ve sosyal problem çözme becerilerine etkisinin incelenmesi. Ahi Evran Üniversitesi Kırşehir Ĕgitim Fakültesi Dergisi (KEFAD), 18(2), 135-153.

Doppelt, Y., Mehalik, M. M., Schunn, C. D., Silk, E., \& Krysinski, D. (2008). Engagement and achievement: A case study of design- based learning in a science context. Journal of Technology Education, 19(2), 22-39.

Durakoğlu, A. (2011). Maria Montessori’ye göre okul öncesi çocukluk döneminin özellikleri. Dicle Üniversitesi Ziya Gökalp Ĕ̈itim Fakültesi Dergisi, 16, 133-145.

Elkin, M., Sullivan, A., \& Bers, M. U. (2014). Implementing a robotics curriculum in an early childhood Montessori classroom. Journal of Information Technology Education: Innovations in Practice, 13, 153-169.

Hadzigeorgiou, Y. (2002). Okul öncesi çocuklarda mekanik stabilite kavramının gelişimi üzerine bir çalışma. Fen Eğitimi Araştırmaları, 32(3), 373-391.

Hartzler, D. S. (2000). A meta-analysis of studies conducted on integrated curriculum programs and their effects on student achievement (Unpublished doctoral dissertation). Indiana University, Bloomington.

Heppner, P. P., \& Petersen, C. H. (1982). The development and implications of a personal problem-solving inventory. Journal of Counseling Psychology, 29(1), 6675.

Hobbs, A. (2008). Academic achievement: Montessori and Non-Montessori private school settings (Unpublished doctoral dissertation). University of Houston, Houston.

Judson, E. (2014). Effect of transferring to STEM focused charter and magnet schools on student achievement. The Journal of Educational Research, 107, 255-266.

Kaya, H. İ. (2010). Öğretmen ĕgitiminde yapılandırmacı ögrrenmeye dayalı uygulamaların öğretmen adaylarının problem çözme, eleştirel düşünme ve yaratıcı düşünme eğilimlerine etkileri (Doktora tezi). Atatürk Üniversitesi, Sosyal Bilimler Enstitüsü, Erzurum.

Keçecioğlu, Ö. (2015). MEB okul öncesi ĕgitim programı ve Montessori yaklaşımına göre eğitim alan 5 yaş çocuklarının sosyal becerilerinin incelenmesi (Yüksek lisans tezi). Marmara Üniversitesi, Eğitim Bilimleri Enstitüsü, İstanbul. 
Koçyiğit, S., \& Kayılı, G. (2008). Montessori eğitimi alan ve almayan anaokulu öğrencilerinin sosyal becerilerinin karşılaştırılması. Selçuk Üniversitesi Mesleki Ĕ̈itim Fakültesi Dergisi, 20, 511-516.

Korkmaz, H. E. (2005). Montessori metodu ve Montessori okullarl: Türkiye`de Montessori okullarının yönetim ve finansman bakımından incelenmesi (Yüksek lisans tezi). Marmara Üniversitesi, Eğitim Bilimleri Enstitüsü, İstanbul.

Kökdemir, D. (2003). Belirsizlik durumlarında karar verme ve problem çözme (Doktora tezi). Ankara Üniversitesi, Sosyal Bilimler Enstitüsü, Ankara.

Millî Eğitim Bakanlığı (2016). STEM Eğitimi Raporu. Ankara: SESAM.

Miles, M, B. \& Huberman, A. M. (1994). Qualitative data analysis: An expanded Sourcebook. (2nd ed). Thousand Oaks, CA: Sage.

Oğuz, V., \& Köksal-Akyol, A. (2006). Çocuk eğitiminde Montessori yaklaşımı. Çukurova Üniversitesi Sosyal Bilimler Enstitüsü Dergisi, 15(1), 243-256.

Özdağ, S. A. (2014). Montessori metodu'nun eğitim mekânlarına yansıması üzerine kavramsal bir analiz (Yüksek lisans tezi). Karadeniz Teknik Üniversitesi, Fen Bilimleri Enstitüsü, Trabzon.

Sungur-Gül, K., \& Marulcu, İ. (2014). Yöntem olarak mühendislik-dizayna ve ders materyali olarak legolara öğretmen ile öğretmen adaylarının bakış açılarının incelenmesi. Turkish Studies, 9(2), 761-786.

Strong, M. G. (2013). Developing elementary math and science process skills through engineering design instruction (Order No. 1537547). Available from ProQuest Dissertations \& Theses Global.

Sullivan, F. V. (2008). Robotics and science literacy: Thinking skills, science process skills and systems understanding. Journal of Research in Science Teaching, 45(3), 373-394.

Şahin, A. (2013). STEM clubs and science fair competitions: Effects on post-secondary matriculation. Journal of STEM Education, 14(1), 5-11.

Şahin, A., Ayar, M. C., \& Adigüzel, T. (2014). Fen, teknoloji, mühendislik ve matematik içerikli okul sonrası etkinlikler ve öğrenciler üzerindeki etkileri. Kuram ve Uygulamada Eğitim Bilimleri, 14(1), 297-322.

Taylan, S. (1990). heppner'in problem çözme enventerinin uyarlama, güvenilirlik ve geçerlilik çalışmaları (Yayımlanmamış yüksek lisans tezi). Ankara Üniversitesi, Sosyal Bilimler Enstitüsü, Ankara.

Tarkın-Çelikkıran, A., \& Aydın-Günbatar, S. (2017). Kimya öğretmen adaylarının FeTeMM uygulamaları hakkındaki görüsslerinin incelenmesi. Yüzüncü Yıl Üniversitesi Eğitim Fakültesi Dergisi, 14(1), 1624-1656.

Timur, S., Timur, B., Yalçınkaya-Önder, E., \& Küçük, D. (2020). Attitudes of the students attending out-of-school STEM workshops towards STEM education. Journal of Theoretical Educational Science, 13(2), 334-351. DOI: 10.30831/akukeg.582388

Uyanık-Balat, G., \& Günşen, G. (2017). Okul öncesi dönemde STEM yaklaşımı. Akademik Sosyal Araştırmalar Dergisi, 5(42), 337-348. 
Yaman, S., \& Yalçın, N. (2005). Fen bilgisi öğretiminde probleme dayalı öğrenme yaklaşımının yaratıcı düşünme becerisine etkisi. İlköğretim-Online, 4(1), 42-52.

Yıldırım, A., \& Şimşek, H. (2008). Sosyal bilimlerde nitel araştırma yöntemleri. Seçkin Yayınları, Ankara.

Yıldırım, B. (2019). Fen bilgisi öğretmen adaylarının STEM eğitiminde biyomimikri uygulamalarına yönelik görüşleri. Gazi Üniversitesi Gazi Eğitim Fakültesi Dergisi, 39(1), 63-90.

Yuvacı, Z., \& Dağlıoğlu, E. H. (2018). Okul öncesi eğitim alan çocukların ve bulundukları sınıf ortamının yaratıcılık düzeyleri arasındaki ilişkisinin incelenmesi. Erken Çocukluk Çalışmaları Dergisi, 2(2). 234-256.

Yücesan, Y. (2017). Montessori eğitiminin okul öncesi dönem çocukların problem çözme becerileri ve problem davranışları üzerine etkisinin incelenmesi (Yüksek lisans tezi). Karabük Üniversitesi, Sağlık Bilimleri Enstitüsü, Karabük.

Zhou, K. Z., \& Wu, F. (2010). Technological capability, strategic flexibility, and product innovation. Strategic Management Journal, 31(5), 547-561. 